\title{
PENGARUH METODE OPEN ENDED DAN STAD TERHADAP KEMAMPUAN PEMECAHAN MASALAH MATEMATIKA DITINJAU DARI PRESTASI BELAJAR
}

\section{THE EFFECT OF THE OPEN-ENDED AND STAD METHODS ON THE MATHEMATICAL PROBLEM SOLVING ABILITY VIEWED FROM LEARNING ACHIEVEMENT}

\author{
Alman $^{1}$, Pardjono ${ }^{2}$, Almuhaimin S, $\mathrm{I}^{3}$ Ahmad $\mathrm{Y}^{4}$, Asrul $^{5}$ \\ Program Studi Pendidikan Guru Sekolah Dasar, Universitas Pendidikan Muhammadiyah Sorong \\ 1 almankuntara87@gmail.comyahoo.co.id.
}

\begin{abstract}
Abstrak
Penelitian ini merupakan penelitian kuasi eksperimen yang menggunakan factorial design. Penelitian ini bertujuan untuk menemukan fakta-fakta akibat dari perbedaan pengaruh metode Open ended dengan metode STAD terhadap pemecahan masalah matematika peserta didik ditinjau dari prestasi belajar. Dimana prestasi belajar digolongkan menjadi dua tingkat yaitu prestasi tinggi dan rendah.Populasi penelitian ini adalah peserta didik kelas V SD Negeri Serayu.Data di analisis dengan uji univariat ANAVA. Hasil penelitian adalah (1). Ada perbedaan kemampuan pemecahan masalah matematika peserta didik yang diajarkan dengan metodeopen ended dan metode STAD. (2). Nilairata-rata posttest prestasi open ended tertinggi peserta didik adalah 95,71 dan nilai rata-rata rendah 63,92 . Nilai rata-rata total prestasi open ended adalah 81,04 . Sedangkan nilai rata-rata postest prestasi STAD tertinggi peserta didik adalah 95,50 dan nilai rata-rata posttest prestasi STAD rendah 70,00. Nilai rata-rata total posttest prestasi peserta didik adalah 89,13. (3). Tidak ada interaksi antara metode open ended dan metode STAD .
\end{abstract}

Kata Kunci: Metode open ended, metode STAD, kemampuan pemecahan masalah, prestasi belajar

\begin{abstract}
This study was quasi-experimental research using the factorial design. This study aims to find the facts as a result of differences in the influence of the open-ended method and STAD method for solving mathematical problem of the students' in term of learning achievement. The population wasfive grade students of State Primary School Serayu, Yogyakarta. The data analysis wereusing theunivariate ANAVA. The results of the study are as follows: (1). There are differences in the mathematical problem solving ability of the students who are taught using the open-ended method and STAD method. (2). The average score open ended post-test highest achievement of the student is 95.71 and the average scorelower is 63.92. The average score of total achievement is open ended 81.04. While the average score STAD post-test highest achievement of the students is 95.50 and the average score of more low is 70.00. The average score of total post-test students' achievements is 89.13. (3). There is no interaction between of the open-ended method and STAD method.
\end{abstract}

Keywords: $\quad$ open-ended method, STAD method, problem solving ability, learning achievement 


\section{Pendahuluan}

Metode open ended atau masalah terbuka merupakan metode yang muncul atas dasar pendekatan open ended yang telah populer diterapkan pada pelajaran matematika. Metode pembelajaran open ended merupakan salah satu upaya inovasi pendidikan yang pertama kali dilakukan oleh para ahli pendidikan matematika Jepang. Pada prinsipnya metode open ended mirip dengan pembelajaran berbasis masalah yaitu suatu metode pembelajaran yang dalam prosesnya dimulai dengan memberi suatu masalah kepada peserta didik. Penerapan metode Open ended (OE) sebagai metode pembelajaran yang merujuk pada pandangan tentang suatu proses yang sifatnya masih sangat umum, yang di dalamnya mewadahi, menginspirasi, dan menguatkan metode pembelajaran berdasarkan teori.

Dengan demikian, metode open ended memberikan kesempatan kepada peserta didik untuk mengivestigasi berbagai strategi yang diyakininya sesuai dengan kemampuan mengintegrasikan permasalahan. Tujuannya adalah agar kemampuan berpikir peserta didik dalam menyelesaikan pemecahan masalah matematika dapat berkembang secara maksimal melalui proses belajar mengajar.

Banyak penelitian yang menunjukkan bahwa pembelajaran kooperatif (Students Teams Achievement Division) seperti pembelajaran kalaboratif teryata lebih efektif daripada pengajaran yang dilakukan oleh guru. Hal ini disebabkan oleh latar belakang pengalaman dan pengetahuan para peserta didik yang lebih mirip satu dengan yang lainnya dibandingkan dengan skemata guru. Tidak selamanya, semua metode pembelajara dengan bekerja sama dalam kelompok bisa berhasil dengan efektif. Metode Students Teams Achievement Division dalam pembelajaran kooperatif baru bisa mencapai hasil yang maksimal bila menerapkan lima unsur (1) saling ketergantungan positif, (2) tanggung jawab perseorangan, (3) tatap muka, (4) komunikasi antar anggota kelompok, dan (5) evaluasi proses kelompok (Hamruni, 2013, p. 217).
Pembelajaran kooperatifmerupakan metode pembelajaran yang menugaskan kepada peserta didik untuk membuat kelompok-kelompok kecil di kelas ataudi lingkungan di mana mereka belajar secara bersama-sama, sehingga dapat meningkatkan kepercayaan diri secara individu (Akçay\& Doymuş, (2014, p.18). Hal senada juga di definisikan oleh Cohen, et, al, (2004, p.3) Pembelajaran kooperatif memungkinkan semua peserta didik untuk bekerja sama, setiap peserta didik memiliki pengalaman dan peran guru dalam proses belajar mengetahui pengetahuan setiap peserta didik dan menghormati berbagai keterampilan dan gaya belajar yang berbeda.

Dengan demikian, melalui metode Students Teams Achievement Division (STAD) peserta didik dapat bekerja sama dalam satu tim pada proses pembelajaran. Kegiatan pembelajaran bertujuan untuk meningkatkan kepercayaan diri secara individu dalam bersosial sehingga dapat meningkatkan kemampuan dan keterampilan peserta didik dalam memecahkan masalah matematika.

Di Sekolah Dasar semua mata pembelajaran di integrasikan dalam satu tema. Salahsatunya materi pembelajaran yang diintegrasikan dengan pembelajaran yang lain adalah pembelajaran matematika. Pembelajaran matematika merupakan mata pembelajaran yang wajib diajarkan disemua jenjang pendidikan, dimulai dari jenjang sekolah dasar hingga perguruan tinggi(Hendrawan, et al, 2013, p. 3) Matematika merupakan ilmu yang dapat memecahkan permasalahan yang dihadapi oleh peserta didik dalam kehidupan sehari-hari dengan menggunakan langkah-langkah yang dikemukakan oleh Polya. Ada empat langkah pemecahan masalah menurut Polya dalam (Bennett, Burton, \& Nelson, 2012, pp.4-5), yaitu,(1) memahami masalah, (2) membuat 
rencana, (3) melaksanakan rencana, dan (4) melihat kembali.Masalah merupakan pertanyaan yang harus dijawab atau direspon. Masalah adalah situasi di mana seseorang menginginkan sesuatu tetapi tidak mengetahui langsung cara yang harus dilakukan untuk mendapatkannya. Leiba, (2013, p. 37), menyatakan bahwa pemecahan masalah dapat dianggap sebagai situasi dimana peserta didik tidak dapat menyelesaikan soal dengan prosedur rutin yang biasa ia gunakan.

Motivasi peserta didik menjadi menurun saat proses belajar mengajar di dalam kelas di pengaruhi oleh kegiatan pembelajaran yang monoton pada apa yang ada di buku pegangan peserta didik dan buku pegangan guru serta LKS peserta didik.

Permasalahan rendahnya hasil belajar matematika masih ditemukan dilingkungan sekolah dasar, salah satunya di SD Negeri Serayu Yogyakarta. Hasil wawancara yang dilakukan dengan salah satu guru kelas V diperoleh informasi bahwa metode yang dilakukan masih menggunakan metode yang ada di buku pegangan guru yakni buku kurikukulum 2013. Langkah-langkah pembelajaran yang dilakukan sesuai dengan

\section{Metode Penelitian}

Subjek penelitian ini adalah peserta didik kelas V A dan V C SD Negeri Serayu Yogyakarta tahun ajaran 2014/2015 yang terdiri dari 26 peserta didik dan 24 peserta didik. Penelitian ini merupakan kuasi eksperimen dengan desain penelitian factorial design. Pada desain ini ingin melihat perbedaan dari kedua kelompok dengan menggunakan metode open ended dan metode STAD. Adapun teknik pengumpulan data yang digunakan dalam penelitian ini adalah sesudah diberikan perlakuan yaitu dengan memberikan posttest kemampuan pemecahan matematika. Berikut merupakan tabel reliabilitas dari ke dua metode.

Tabel 1. Nilai Alpha Cronbach

\begin{tabular}{crcc}
\hline Metode & Nilai $\alpha$ & $\mathrm{N}$ & Ket \\
\hline Open Ended & 0.739 & 15 & Reliabel \\
\hline
\end{tabular}

apa yang ada dibuku pegangan guru. Hal ini dapat dilihat dari dokumen hasil belajar atau laporan pendidikan akhir semester masih terdapat nilai matematika peserta didik rendah. Nilai rata-rata matematika peserta didik masih berada di bawah kriteria ketuntasan minimal (KKM) yang telah ditetapkan oleh sekolah yang bersangkutan.

Hal ini disebabkan karena dalam proses pembelajaran matematika masih ada sebagian guru di sekolah dasar masih menggunakan metode lama atau metode konvesional. Metode konvesional adalah metode pembelajaran ceramah yang cakupannya hanya berpusat pada guru. Mengingatmasalah tersebut sangat penting, maka dilakukan penelitian tentang perbedaan pengaruh metode open ended dengan metode STAD terhadap kemampuan pemecahan masalah matematika peserta didik kelas V SD Negeri Serayu Yogyakarta ditinjau dari prestasi belajar dengan tujuan untuk (1). mengetahui kemampuan pemecahan masalah matematika peserta didik melalui implementasi metode open ended dan metode STAD (2). Untuk mengetahui metode yang lebih baik di gunakan dalam pemecahan masalah matematika (3). Untuk mengetahui perbedaan kemampuan pemecahan masalah matematika melalui metode open ended dan metode STAD.

\begin{tabular}{llll} 
STAD & 0,744 & 15 & Reliabel \\
\hline
\end{tabular}

Teknik analisis data yang digunakan dalam penelitian ini adalah analisis descriptive statistic. Analisis deskriptif untuk mendeskripsikan keadaan sesudah diberikan perlakuan pada kedua kelas ditinjau dari masing-masing variabel terikatnya. Perlu diketahui bahwa keefektifan pembelajaran matematika dapat ditentukan berdasarkan kriteria pencapaian tujuan pembelajaran yang ditunjukkan dengan ketuntasan belajar peserta didik dalam belajar matematika. Peserta didik dikatakan tuntas belajar ketika rata-rata kelas melebihi KKM 60 untuk kemampuan pemecahan masalah matematika skor maksimalnya adalah 100 sehingga peserta didik dikatakan tuntas apabila rata-rata skor peserta didik melebihi skor 60. Sementara itu suatu metode dikatakan efektif ditinjau dari 
prestasi belajar matematika peserta didik ketika prestasi dalam pembelajaran matematika masuk pada kategori tinggi.

Data-data yang diperoleh selama penelitian berlangsung harus memenuhi uji asumsi terlebih dahulu sebelum melalui proses analisis. Uji asumsi yang harus dipenuhi adalah uji normalitas dengan menggunakan descriptive statistic melalui explore dibawah 0,05 maka dapat dikatakan bahwa data tersebut berdistribusi normal. Selain itu, homogenitas kedua kelompok di uji dengan menggunakan deskriptive statisticexplore. Jika nilai signifikansi yang diperoleh lebih dari 0,05, maka matriks varians kedua populasi tersebut homogen. Setelah melewati proses uji asumsi, maka dilanjut dengan One sample t-test untuk menganalisis keefektifan dari metode ditinjau dari masing-masing variabel terikatnya. Sementara itu, analisis perbedaan keefektifan antara metode open ended dan metode STAD dilakukan dengan uji univariate Analysis of Variance (ANAVA). Taraf signifikansi yang digunakan pada uji keefektifan adalah 0,05. Sedangkan uji univariat dilakukan dengan menggunakan independent sample $t$ test dengan taraf signifikansi 0,05 . Uji ini digunakan untuk melihat mana yang lebih efektif antara metode open ended dan metode STAD.

\section{Hasil Penelitian dan Pembahasan}

Adapun hasil analisis data statistik deskriptif disajikan pada tabel 2 .

Tabel 2. Deskripsi hasil posttest kemampuan pemecehan masalah matematika dengan metode open ended $(\mathrm{OE})$ dan metode STAD

\begin{tabular}{lcc} 
Atribut & \multicolumn{2}{c}{ Metode } \\
& Open Ended & STAD \\
\hline Subjek (N) & 26 & 24 \\
Rata-rata & 81,04 & 89,13 \\
Standar. Dev & 17,637 & 13,126 \\
Varians & 311,078 & 172,288 \\
Nilai Maks & 100 & 100 \\
Nilai Min & 60 & 60 \\
\hline
\end{tabular}

Berdasarkan tabel 2nilai rata-rata posttest untuk metode open ended adalah 81.04 dan posttest untuk metode STAD adalah 89,13. Sedangkan nilai maksimal dan minimal kedua kelas adalah 100 dan 60. Adapun kriteria ketuntasan maksimal (KKM) yang di tetapkan SD serayu khususnya matematika adalah 60, maka kedua kelas sudah memenuhi KKM tersebut. Pengelompokkan kategori skor dibedakan antara tinggidan rendah. Ukuran penyebaran data posttest berdasarkan penggolongan prestasi tinggi dan rendah disajikan pada tabel 3 dibawah ini.

Tabel 3. Data penyebaran posttest pada prestasi tinggi dan prestasi rendah terhadap metode

\begin{tabular}{lllll}
\hline Prestasi & & Mean & Std. Dev & N \\
\hline Tinggi & Metode & & & \\
& Open ended & 95,71 & 8,516 & 14 \\
& STAD & 95,5 & 7,602 & 18 \\
& Total & $\mathbf{9 5 , 5 9}$ & $\mathbf{7 , 8 8 2}$ & $\mathbf{3 2}$ \\
Rendah & Open ended & 63,92 & 5,230 & 12 \\
& STAD & 70,00 & 3,286 & 6 \\
& Total & $\mathbf{6 5 , 9 4}$ & $\mathbf{5 , 4 3 9}$ & $\mathbf{1 8}$ \\
Total & Open ended & 81,04 & 17,637 & 26 \\
& STAD & 89,13 & 13,126 & 24 \\
& Total & $\mathbf{8 4 , 9 2}$ & $\mathbf{1 6 , 0 0 7}$ & $\mathbf{5 0}$ \\
\hline
\end{tabular}

Berdasarkan tabel data penyebaran posttest kemampuan pemecahan masalah dari prestasi belajar dapat di kelompokkan atas dua, yaitu rata-rata kelompok yang berprestasi tinggi, rendah, dan total dari kedua kelompok tersebut. Berdasarkan tabel 3, diperoleh informasi sebagai berikut: (1) peserta didik yang mendapatkan prestasi tinggi dan metode open ended berjumlah 14 orang dengan nilai rata-rata 95,71 dan standar deviasinya adalah 8,516 . Sedangkan peserta didik yang mendapatkan prestasi tinggi dengan metode 
STAD berjumlah 18 orang dengan nilai ratarata 95,50 dan standar devisianya adalah 7,602. Jumlah peserta didik secara keseluruhan yang mendapatkan prestasi tinggi baik dengan metode open ended maupun metode STAD adalah 32 orang, nilai rata-rata prestasi tinggi dari kedua metode tersebut adalah 95,59 dan standar devisiasinya adalah 7,882, (2) peserta didik yang mendapatkan prestasi baik itu prestasi tinggi maupun rendah dengan metode open ended berjumlah 26 orang dengan nilai rata-rata 63,92 dan standar deviasinya adalah 5,230 . Sedangkan peserta didik yang mendapatkan prestasi rendah dengan metode STAD berjumlah 6 orang dengan nilai rata-rata 70,00 dan standar devisianya adalah 3,286. Jumlah peserta didik secara keseluruhan yang mendapatkan prestasi rendah baik dengan metode open ended maupun metode STAD Hasil Uji Hipotesis

Hipotesis penelitian yang diuji adalah terdapat perbedaan yang signifikan melalui kemampuan pemecahan masalah matematika peserta didik yang mengikuti pembelajaran matematika dengan metode STAD dengan peserta didik yang mengikuti metode open ended $(\mathrm{OE})$. Pada uji hipotesis ini menggunakan uji $\mathrm{t}$ independent. Berdasarkan hasil perhitungan uji prasyarat yang menunjukkan bahwa hasil data posttest dari kedua kelompok eksperiment adalah normal dan homogen serta jumlah peserta didik pada setiap kelas berbeda maka uji-t one sample test ini digunakan. Adapun hasil analisis untuk uji-t dapat disajikan pada tabel 4 .

Tabel 4. Hasil uji hipotesis

\begin{tabular}{lccccl}
\hline Prestasi & $\mathbf{T}_{\text {tab }}$ & $\mathbf{T}_{\text {hit }}$ & $\mathbf{N}$ & Sig. & Ket. \\
\hline OE & 1,71 & 22,855 & 26 & 0,00 & $\mathrm{H}_{0}$ ditolak \\
STAD & 1,71 & 33,264 & 24 & 0,00 & $\mathrm{H}_{0}$ ditolak \\
\hline
\end{tabular}

adalah 18 orang, nilai rata-rata prestasi rendah dari kedua metode tersebut adalah 65,94 dan standar devisiasinya adalah 5,439, dan (3) total peserta didik yang mendapatkan prestasi tinggi dan rendah dengan metode open ended (OE) berjumlah 26 orang dengan nilai rata-rata 81,04 dan standar deviasinya adalah 17,637. Sedangkan total peserta didik yang mendapatkan prestasi tinggi dan rendah dengan metode STAD berjumlah 24 orang dengan nilai rata-rata 89,13 dan standar devisianya adalah 13,126. Jumlah keseluruhan peserta didik yang mendapatkan prestasi tinggi dan rendah baik dengan metode open ended maupun metode STAD berjumlah 50 orang. Total nilai rata-rata prestasi dari kedua metode tersebut adalah 84,92 dan standar devisiasinya adalah 16,007 .

Berdasarkan hasil analisis yang diperoleh uji one sample $t$ test dengan $t_{\text {hitung }}=22,855$ dan $\mathrm{t}_{\text {tabel }}=1,71, \mathrm{t}_{\text {hitung }}>\mathrm{t}_{\text {tabel }}$ dengan signifikan 0,00 $<0,05$ untuk metode open ended dan untuk metode STAD $t_{\text {hitung }}=33,264$ dan $t_{\text {tabel }}=1,71$, $t_{\text {hitung }}>t_{\text {tabel }}$ dengan signifikan $0,00<0,05$ artinya bahwa $\mathrm{H}_{0}$ di tolak dan $\mathrm{H}_{1}$ diterima, sehingga dapat disimpulkan bahwa tidak terdapat perbedaan metode open ended dan metode STAD terhadap kemampuan pemecahan masalah matematika peserta didik ditinjau dari prestasi belajar.

Pengujian hipotesis statistik pada penelitian ini dilakukan dengan menggunakan analisis varians (ANAVA) yang dilanjutkan dengan uji Tukey. Analisis varians digunakan untuk menguji perbedaan dan interaksi variabel bebas dengan metode open ended dan metode STAD terhadap variabel terikat prestasi belajar, hasil analisis data dengan uji ANAVA. Disajikan pada tabel 5.

Tabel 5. Uji Anava

\begin{tabular}{|c|c|c|c|c|c|c|c|}
\hline \multirow[t]{2}{*}{ Sumber varians } & \multirow[t]{2}{*}{ JK } & \multirow[t]{2}{*}{ dk } & \multirow[t]{2}{*}{ MK } & \multirow[t]{2}{*}{$\mathbf{F}$} & \multicolumn{2}{|c|}{$\mathbf{F}_{\text {tabel }}$} & \multirow[t]{2}{*}{ Sig. } \\
\hline & & & & & 0,05 & $\mathbf{0 , 0 1}$ & \\
\hline Prestasi (antar kolom) & 9254,109 & 1 & 9354,109 & 184,3 & 4,04 & 7,19 & 0,00 \\
\hline Metode (antar baris) & 43,186 & 1 & 43,186 & 0,851 & 4,04 & 7,19 & 0,361 \\
\hline $\begin{array}{l}\text { Kekeliruan } \\
\text { kelompok }\end{array}$ & 373126,000 & 47 & 50,755 & & & & \\
\hline Jumlah & 12555,680 & 50 & & & & & \\
\hline
\end{tabular}


Dari tabel diatas hasil analisis ANAVA dapat dijelaskan bahwa: (1) pada baris interaksi tampak bahwa tidak terdapat interaksi kedua faktor antara metode dan prestasi. Efek metode dan prestasi signifikan.Hal ini menunjukkan bahwa interaksi antara kedua faktor antara metode dan prestasi yang menyatakan hipotesis Ho tidak ada interaksi diterima dan yang menyatakan ada interaksi $\left(\mathrm{H}_{1}\right)$ ditolak. Hal ini berarti bahwa tidak ada interaksi antara metode open ended dan metode STAD terhadap kemampuan pemecahan masalah matematika peserta didik dilihat melalui prestasi belajar. Pada baris metode terdapat perbedaan antara kolom nilai $\mathrm{F}=0,851$. hal ini menunjukkan bahwa hipotesis Ho yang menyatakan bahwa ada perbedaan kemampuan pemecahan masalah matematika yang diajarkan dengan metode open ended dengan peserta didik yang diajarkan dengan metode STAD ditolak atau hipotesis penelitian (Ho) ditolak. Dengan demikian dapat dinyatakan bahwa tidak ada perbedaan kemampuan pemecahan masalah dengan menggunakan metode open ended $(\mathrm{OE})$ dengan metode STAD. Dari data yang diperoleh dari hasil posstest yang diajarkan dengan metode open ended tidak mempunyai perbedaan yang signifikan jika dibandingkan dengan metode

Uji lanjut (Uji Tukey's)

Kedua rata-rata prestasi pemecahan masalah matematika dengan subjek yang tidak indentik maka dilakukan uji lanjut setelah ANAVA yaitu uji Tukey's (untuk mengukur sampel subjek yang berbeda). Uji Tukey's dan
STAD. Hal ini dapat dilihat melalui rata-rata hasil posttest peserta didik dengan metode open ended $\bar{X}=81,04$ dan untuk metode STAD $\bar{X}=89,13$, (2) pada baris prestasi pemecahan masalah nilai $\mathrm{F}=184,300$, ini menunjukkan bahwa hipotesis nol (Ho) yang menyatakan bahwa tidak ada perbedaan kemampuan pemecahan masalah matematika peserta didik dengan kategori rata-rata tinggi dan kategori rata-rata rendah ditolak, atau hipotesis alternative diterima. Dengan demikian dapat dinyatakan bahwa terdapat perbedaan kemampuan pemecahan masalah yang signifikan antara peserta didik yang mempunyai prestasi tinggi dan rendah terhadap kemampuan pemecahan masalah. Dari data hasil posttest peserta didik yang memperoleh rata-rata peserta didik yang memiliki nilai prestasi tinggi terhadap kemampuan pemecahan masalah matematika adalah 95,71 dan rata-rata nilai prestasi rendah peserta didik terhadap kemampuan pemecahan masalah matematika adalah 63,92.

Dari analisis penelitian tersebut terbukti bahwa tidak ada interaksi antara metode dengan prestasi terhadap pemecahan masalah matematika peserta didik ditinjau dari prestasi belajar.

Bonferroni ini dilakukan untuk mengetahui kelompok yang berbeda dan yang mempunyai kemampuan pemecahan masalah yang paling baik dan efektif. Hasil uji Tukey's disajikan dalam tabel 6.

Tabel. 6. Analisis Uji Tukey Posttest

\begin{tabular}{llccc}
\hline (I)Kelompok & $(\mathbf{J})$ Kelompok & Mean Defference (I-J) & Std. Error & Sig. \\
\hline Prestasi OE T & Prestasi OE R & $31,798^{*}$ & 2,770 & 0,00 \\
& Prestasi STAD R & $25,714^{*}$ & 3,435 & 0,00 \\
Prestasi OE R & Prestasi OE T & $-31,798^{*}$ & 2,770 & 0,00 \\
& Prestasi STAD T & $-31,583^{*}$ & 2,624 & 0,00 \\
\multirow{2}{*}{ Prestasi STAD T } & Prestasi OE R & $31,583^{*}$ & 2,624 & 0,00 \\
& Prestasi STAD R & $25,500^{*}$ & 3,319 & 0,00 \\
Prestasi STAD R & Prestasi OE T & $-25,714^{*}$ & 3,435 & 0,00 \\
& Prestasi STAD T & $-25,500^{*}$ & 3,319 & 0,00 \\
\hline
\end{tabular}

Tabel7.Homogeneous Subsetskelompok prestasi tinggi dan prestasi rendah pada metode open ended (OE) dan STAD

\section{Kelompok $\quad$ N $\quad$ Subset for alpha $=\mathbf{0 , 0 5}$}




\begin{tabular}{cccc}
\hline & & $\mathbf{1}$ & $\mathbf{2}$ \\
\hline Prestasi OE R & 12 & 63,92 & \\
Prestasi STAD R & 6 & 70,00 & \\
Prestasi OE T & 14 & & 95,71 \\
Prestasi STAD T & 18 & & 95,50 \\
Sig. & & 0,207 & 1,000 \\
\hline
\end{tabular}

Analisis berdasarkan tabel 6, pada kolom mean defference terlihat adanya tanda ' $*$ ' pada angka setiap baris. Hal ini menunjukkan perbedaan rata-rata tersebut ternyata signifikan. Sedangkan analisis berdasarkan tabel 7, akan dicari group atau subset mana saja yang mempunyai perbedaan rata-rata yang tidak berbeda secara signifikan. Pada subset 1 , terlihat bahwa hanya group dengan metode open ended dengan rata-rata 63,92. Sehingga dapat dikatakan rata-rata kemampuan pemecahan masalah matematika dengan metode open ended berbeda dengan metode lain yaitu metode STAD. Hal ini dapat kita lihat pada kolom pada subset 1 , dan 2 memiliki nilai yang berbeda pada kelompok prestasi rendah sedangkan pada kolom subset kedua berbeda dengan kolom yang ketiga. Sehingga dengan demikian hipotesis pertama yang mengatakan bahwa ada perbedaan yang signifikan mengenai kemampuan pemecahan masalah matematika yang disebabkan oleh perbedaan metode open ended dan metode STAD diterima.
Pada tabel 7. terlihat bahwa rata-rata kemampuan pemcahan masalah matematika yang paling tinggi adalah 95.71, sedangkan dengan metode open ended memiliki rataratanya 81,04. Dengan demikian dapat disimpulkan bahwa pembelajaran dengan metode STAD lebih baik atau lebih efektif dalam meningkatkan kemampuan pemecahan masalah matematika peserta didik.

Dalam kasus ini uji Anava satu factor digunakan untuk menguji apakah ada perbedaan yang signifikan pada kemampuan pemecahan masalah matematika ditinjau dari prestasi belajar.

Hipotesis untuk kasus ini :

Ho = tidak ada perbedaan rata-rata kemampuan pemecahan masalah matematika dengan metode open ended dan metode STAD

$\mathrm{H} 1$ = Ada perbedaan rata-rata kemampuan pemecahan masalah matematika dengan metode open ended dan metode STAD.

Berdasarkan nilai rata-rata kemampuan pemecahan masalah matematika peserta didik.

Tabel 8. Data perbedaan hasilrata-rata posttest kemampuan pemecahan masalah antara metode open endeddan metode STAD dengan prestasi

\begin{tabular}{|c|c|c|}
\hline Prest & Eelas & Posttest Kelas \\
\hline $\begin{array}{l}\text { Nilai } \bar{X}_{\text {Va }} \\
\mathbf{8 5 , 1 5}\end{array}$ & $\begin{array}{l}\text { Nilai } \bar{X}_{\text {Vc }} \\
\mathbf{7 4 , 2 5}\end{array}$ & $\begin{array}{ll}\bar{X} & \text { M. STAD } \\
\mathbf{8 9 , 1 3}\end{array}$ \\
\hline
\end{tabular}

Berdasarkan tabel 8 rata-rata prestasi belajar peserta didik sebelum dilakukan perlakuan dengan metode memiliki nilai rata-rata 85,15 untuk kelas VA dan nilai rata-rata prestasi belajar untuk kelas VC adalah 74,25. Setelah dilakukan perlakuan hasil posttest diperoleh rata-rata kelas dengan metode yang berbeda yakni metode open ended dan metode STAD terhadap kemampuan pemecahan masalah matematika peserta didik, kelas dengan metode open ended memperoleh nilai rata-rata 81,04 dan kelas dengan metode STAD memperoleh rata-rata 89,15. Hal ini menunjukan bahwa hasil yang diperoleh memiliki perbedaan antara pembelajaran dengan menggunakan metode open ended dengan metode STAD. Hal ini berdasarkan nilai rata-rata posttest yang di miliki oleh setiap kelas. Dari data kedua metode ini dapat kita simpulkan bahwa metode STAD sangat cocok digunakan untuk diterapkan oleh guru dalam pembelajaran pemecahan masalah matematika.

Uji signifikansi pengaruh interaksi antara kemampuan pemecahan masalah matematika 
dengan menggunakan metode open ended(OE) dan metode STAD, dan prestasi belajar.

Pengujian hipotesis dengan menggunakan Anava untuk interaksi dua factor.Uji ini bertujuan untuk mengetahui apakah ada hubungan yang signifikan antara kedua factor. Dalam kasus ini akan diuji apakah ada interaksi pengaruh yang signifikan mengenai kemampuan pemecahan matematika yang disebabkan oleh metode open ended dan metode STAD ditinjau dari prestasi belajar.

Hipotesis untuk kasus ini adalah sebagai berikut:

Ho = Tidak ada pengaruh interaksi yang signifikan mengenai kemampuan pemecahan masalah matematika dengan metode open ended dan metode STAD ditinaju dari prestasi belajar.

$\mathrm{H} 1$ = Ada pengaruh interaksi yang signifikan mengenai kemampuan pemecahan masalah matematika dengan metode open ended dan metode STAD ditinaju dari prestasi belajar. Dasar pengambilan keputusan berdasarkan nilai probabilitas: (1) jika signifikansi $p>0.05$, Ho diterima, dan (2) jika probabilitas $<0.05$ Ho ditolak.

Dari tabel test of between subject effectsdapat dilihat tidak ada interaksi antara metode dengan prestasi. Hal ini menunjukkan bahwa signifikansi pada metode open ended dan metode STAD ditinjau dari prestasi belajar ditolak.

\section{Pembahasan}

Hasil penelitian terhadap pengaruh masing-masing variabel bebas dan variabel terikat pada peserta didik kelas V SD Negeri Serayu yang dijadikan sebagai kelas eksperimen dalam penerapan metode open ended dan metode STAD. Kedua kelas eksperimen tersebut justru efektif dalam meningkatkan kemampuan dalam memecahkan masalah matematika.Hal ini disebabkan oleh beberapa faktor yang pertama adalah terkait dengan fasilitas yang di sediakan oleh pihak sekolah seperti komputer/laptop, projector, buku pegangan untuk peserta didik, LKS, dan ruangan belajar yang nyaman yang dilengkapi dengan kipas angin. Selain sarana yang disiapkan dari pihak sekolah, dalam proses belajar mengajar dengan menerapkan metode yang di eksperimenkan guru selalu memberikan waktu yang lebih sesuai dengan waktu yang sudah ditetapkan namun waktu yang lebih digunakan untuk bertanya dan berdiskusi serta menjawab pertanyaan yang ada dalam soal latihan yang diberikan oleh guru. Guru tidak langsung menjawab soal latihan yang dikerjakan oleh peserta didik jika ada soal yang sulit dikerjakan oleh peserta didik. Hasil latihan yang dikerjakan oleh peserta didik dibagikan langsung kepada peserta didik, agar mereka dapat mengetahui kemampuan masing-masing peserta didik baik itu secara kelompok maupun secara individu.Dengan demikian peserta didik dapat mengetahui letak kesalahannya.

Penelitian ini memliki dua kelas eksperimen yakni kelas eksperimen I adalah kelas VA dengan menggunakan metode open ended dan kelas eksperimen II adalah kelas VC dengan menggunakan metode STAD. Dalam penelitian ini hasil yang diperoleh dari data yang dianalisis ada 3 yakni pengaruh metode open ended terhadap pemecahan masalah matematika ditinjau dari prestasi belajar, pengaruh metode STAD terhadap pemecahan masalah matematika ditinjau dari prestasi belajar, dan perbedaan metode open ended dan metode STAD terhadap pemecahan masalah ditinjau dari prestasi belajar. Dari ketiga hal tersebut dapat jelaskan sebagai berikut:

Pertama pengaruh metode open ended terhadap pemecahan masalah matematika ditinjau dari prestasi belajar. Berdasarkan hasil penelitian ternyata pembelajaran dengan menerapkan metode open ended efektif ditinjau dari prestasi belajar. Dalam pembelajaran matematika dengan menggunakan metode open ended, peserta didik diberikan kebebasan dan kesempatan untuk mengeluarkan ide-ide atau gagasan berdasarkan pengetahuan awal yang dimiliki oleh pesertadidik untuk menemukan konsep materi yang dipelajari, guru hanya mentansfer ilmu kepada peserta didik. Hal ini, peserta didik terlatih untuk berpikir kritis dalam hal proses pembelajaran sehingga memiliki kemampuan memecahkan masalah yang diberikan oleh guru. Proses penerapan metode open ended dalam pembelajaran pada prinsipnya mengutamakan proses dalam menemukan hasil yang dituju bukan pada langsung hasil semata. Hasil analisis data dengan menggunakan SPSS 21.0 for windows menunjukkan bahwa hasil yang diperoleh $\mathrm{t}_{\text {hitung }}$ $=23,428$. Jika dikaitkan dengan kriteria pengujian, $t_{\text {hitung }}>t_{\text {tabel }}=23,428$, maka $\mathrm{H}_{0}$ 
ditolak. Jadi disimpulkan bahwa rata-rata kemampuan pemecahan masalah matematika peserta didik dengan menggunakan metode Open ended lebih besar dari 81,04, atau dengan kata lain metode Open ended terhadap pemecahan masalah matematika ditinjau dari prestasi belajar lebih efektif,

Kedua pengaruh metode stad terhadap pemecahan masalah matematika ditinjau dari prestasi belajar.Berdasarkan hasil penelitian ternyata pembelajaran dengan menerapkan metode STAD juga efektif ditinjau dari prestasi belajar. Dalam pembelajaran matematika dengan menggunakan metode STAD, peserta didik diberikan tugas oleh guru dalam menyelesaikan masalah dengan waktu yang cukup untuk mendiskusikan masalah dengan tim kelompoknya. Dalam diskusi kelompok peserta didik saling membantu antar teman dalam satu tim, mengajarkan kepada teman yang belum memahami masalah yang diberikan oleh guru sampai betul-betul memahaminya kemudian salah satu peserta didik dari kelompok masingmasingmempresentasikan hasil diskusinya didepan kelas. Guru memperhatikan hasil yang dipresentasikan oleh setiap peserta didik yang mewakili tim/kelompoknya di depan kelas/papan tulis. Kemudian guru memberikan penghargaan berupa pujian yang bersifat motivasi kepada peserta didik yang timnya mencapai kriteria skor yang ditentukan oleh guru.Selain penghargaan yang berupa pujian yang bersifat motivasi, guru juga memberikan penghargaan bagi peserta didik yang skornya lebih dari kriteria yang ditentukan maka peserta didik mendapatkan duapuluh persen dari peningkatan pretasi setiap peserta didik.Hal ini dapat memacu semangat peserta didik untuk memiliki prestasi belajar.

Hasil analisis data dengan menggunakan SPSS 21.0 for windows diperoleh $t_{\text {hitung }}=33,264$. Jika dikaitkan dengan kriteria pengujian, $t_{\text {hitung }}>t_{\text {tabel }}$ $=33,264$ maka $\mathrm{H}_{0}$ ditolak. Jadi disimpulkan bahwa rata-rata kemampuan pemecahan masalah matematika peserta didik dengan menggunakan metode STAD lebih besar dari 89,13 atau dengan kata lain metode STAD terhadap pemecahan masalah matematika ditinjau dari prestasi belajar lebih efektif dari metode open ended.

Ketiga perbedaan antara metode open ended dengan metode stad terhadap kemampuan pemecahan masalah matematika ditinjau dari prestasi belajar. Penerapan metode open ended dan metode STAD terhadap kemampuan pemecahan masalah matematika sama-sama efektif ditinjau dari prestasi belajar. Kedua metode yang diterapkan ini tidak ada perbedaan keefektifan ditinjau dari prestasi belajar. Akan tetapi, dapat dilihat dari nilai rata-rata dan presentasi peserta didik yang memperoleh nilai minimal baik untuk kentutasan belajar. Berdasarkan hasil prestasi open ended tinggi dan prestasi open ended rendah, diperoleh nilai rata-rata prestasi open ended tinggi 95,71 dan nilai rata-rata prestasi Open ended rendah 63,92, dan nilai rata-rata total prestasi open ended adalah 81,04. Sedangkan pada metode STAD nilai rata-rata dan presentasi peserta didik yang memperoleh nilai minimal baik untuk ketuntasan belajar. Berdasarkan hasil prestasi STAD tinggi dan prestasi STAD rendah, diperoleh nilai rata-rata prestasi STAD tinggi 95,50 dan nilai rata-rata prestasi STAD rendah 70,00 dan nilai rata-rata total prestasi STAD adalah 89,13 . Sehingga dapat disimpulkan bahwa terdapat perbedaan keefektifan metode open ended dan metode STAD terhadap kemampuan pemecahan masalah matematika peserta didik ditinjau dari prestasi belajar.

Hasil pengujian hipotesis, Posstest kemampuan pemecahan masalah matematika ditinjau dari prestasi belajar.

Pertama pembahasan Hasil Pengujian Hipotesis.

Ada perbedaan yang signifikan antara prestasi pemecahan masalah matematika dengan menggunakan metode open ended dan metode STAD.

Pada pengujian hipotesis pertama disimpulkan bahwa ada perbedaan yang signifikan mengenai prestasi pemecahan masalah yang disebabkan oleh perbedaan metode open ended dengan metode STAD dan prestasi belajar.Selama proses pembelajaran terjadi biasa saja dan statis, dan masih berpusat pada guru. Pembelajaran kurang memberikan tantangan pada peserta didik untuk lebih berkompetisi dalam hal yang positif.Guru perlu melakukan berbagai inovasi dikelas agar peserta didik menjadi lebih efektif dan dapat menyerap materi pembelajaran dengan baik. Metode pembelajaran dengan menggunakan metode Open ended dan metode STAD memberikan ruang yang luas antara peserta 
didik dalam kelompok untuk saling melengkapi kekurangannya, dan juga metode ini meberikan kemudahan bagi guru untuk melihat kemampuan masing-masing individu, karena kuis-kuis yang diberikan dikerjakan secara individu. Metode open ended memberikan ruang yang seluas-luasnya kepada peserta didik untuk melihat kemampuan baik itu secara individu maupun secara kelompok dengan melakukan diskusi yang bersifat kompetisi dengan mengemukakan pendapat yang berbeda dengan yang lain sehingga dapat menemukan pengetahuan dan wawasan yang baru dalam proses diskusi kelompok dan diskusi kelas.

Hal ini sesuai dengan hasil hipotesis 1, secara keseluruhan terdapat perbedaan yang cukup signifikan antara peserta didik yang belajar dengan menggunakan metode open ended dan metode STAD dengan $\mathrm{F}=0,851, \mathrm{p}=0,361$. Karena probabilitas $>0,05$, maka Ho diterima. Dengan demikian hipotesis pertama yang menyatakan bahwa ada perbedaan yang signifikan mengenai kemampuan pemecahan masalah matematika yang disebabkan oleh perbedaan metode open ended dengan metode STAD ditolak.

Masing-masing metode ini memberikan hasil yang berbeda maka kemudian dilanjutkan dengan uji lanjut anova yaitu dengan ujiTukey. Dari uji Tukey tersebut juga terlihat bahwa penggunaan metode open ended dengan metode STAD memberikan hasil kemampuan pemecahan masalah matematika yang efektif.

Kedua Pembahasan hasil pengujian hipotesis.

Ada perbedaan yang signifikan terhadap kemampuan pemecahan dengan menggunakan metode open ended dan metode STAD dilihat dari prestsi belajar

Pada pengujian hipotesis, disimpulkan bahwa ada perbedaan yang signifikan mengenai kemampuan pemecahan masalah matematika yang dengan menggunakan metode open ended dan metode STAD dilihat dari prestasi belajar.

Sesuai dengan hipotesis berdasarkan tabel test of between subject effects terlihat bahwa $\mathrm{F}$ hitung adalah 184,300 dengan signifikan 0.00. hal ini menunjukkan bahwa signifikansi $p<$ 0.000, maka Ho ditolak, berarti kedua rata-rata kemampuan pemecahan masalah matematika adalah tidak indentik. Dengan demikian, hipotesis kedua yang mengatakan ada perbedaan yang signifikan mengenai kemampuan pemecahan masalah matematika yang disebabkan oleh perbedaan prestasi diterima.

Dengan demikian hipotesis kedua yang mengatakan bahwa ada perbedaan yang signifikan mengenai kemampuan pemecahan masalah matematika yang disebabkan oleh perbedaan tingkat prestasi belajar diterima.

Hipotesis

Ketiga pembahasan hasil pengujian

Tidak ada pengaruh interaksi yang signifikan antara kemampuan pemecahan masalah matematika dengan menggunakan metode open ended, metode STAD, dan Prestasi belajar.

Sesuai dengan hipotesis kedua berdasarkan tabel test of between subject effects dan grafik interaksi metode open ended dengan metode STAD tidak terlihat nilai $F$. Hal ini menunjukkan bahwa signifikansi $\mathrm{p}>$ 0.05, maka Ho ditolak, artinya bahwa tidak ada interaksi mengenai kemampuan pemecahan masalah matematika antara metode open ended, metode STAD, dan Prestasi belajar.

Pada hipotesis pengujian ketiga disimpulkan bahwa tidak ada interaksi pengaruh yang signifikan mengenai kemampuan pemecahan masalah matematika yang disebabkan oleh metode open ended dengan metode STAD dan tingkat prestasi belajar.

Karena metode yang dilakukan dalam pembelajaran dan prestasi peserta didik tidak memberikan pengaruh terhadap kemampuan pemecahan masalah matematika peserta didik, maka berdasarkan uji statistic pula dapat disimpulkan bahwa tidak ada interaksi pengaruh yang signifikan mengenai kemampuan pemecahan masalah matematika yang disebabkan oleh metode open ended dengan metode STAD jika ditinjau dari prestasi belajar. Sehingga hipotesis ketiga yang mengatakan bahwa tidak ada interaksi pengaruh yang signifikan mengenai kemampuan pemecahan masalah matematika 
yang disebabkan oleh metode open ended dengan metode STAD yang ditinjau dari KESIMPULAN

Berdasarkan data hasil penelitian dan pembahasan ada beberapa hal yang dapat disimpulkan: (1) ada perbedaan kemampuan pemecahan masalah matematika peserta didik dengan menggunakan metode open ended dan metode STAD ditinjau dari prestasi belajar, menunjukkan bahwa nilai $\mathrm{F}$ sebesar 0,851 , signifikansinya $=0,00$. Hal ini berarti $\mathrm{H}_{0}$ ditolak dan $\mathrm{H}_{1}$ diterima karena $0,00<0,05$ artinya ada perbedaan metode open ended dengan metode STAD dilihat dari prestasi belajar. Perbedaan antara metode open ended dan metode STAD menunjukkan bahwa metode yang lebih cocok untuk di implementasikan dalam pemecahan masalah matematika adalah metode STAD, (2) ada perbedaan kemampuan pemecahan masalah matematika peserta didik antara metode open ended dan metode STAD menunjukan bahwa pada metode open ended nilai rata-rata prestasi tinggi open ended terhadap kemampuan pemecahan masalah matematika 95.71 dan nilai rata-rata prestasi rendah metode open ended 63,92. Sedangkan pada metode STAD memiliki nilai rata-rata prestasi tinggi terhadap kemampuan pemecahan masalah matematika 89,13 dan nilai rata-rata prestasi rendah terhadap kemampuan pemecahan masalah matematika 70,00 . Sedangkan total nilai ratarata prestasi metode open ended terhadap kemampuan pemecahan masalah matematika adalah 81,04 dan total nilai rata-rata prestsi metode STAD terhadap kemampuan pemecahan masalah matematika adalah 70,00. Dari data kedua metode ini dapat kita simpulkan bahwa rata-rata tertinggi metode Open ended sangat cocok untuk diterapkan pada kelas rendah pada metode STAD atau dengan sebaliknya nilai rata-rata tertinggi pada metode STAD sangat cocok untuk diterapkan pada kelas rendah metode open ended, dan (3) tidak ada interaksi antara metode open ended dan metode STAD terhadap kemampuan pemecahan masalah dilihat dari prestasi belajar menunjukkan bahwa nilai $F$ sebesar 184,300 dan signifikansinya 0.00 . Hal ini menunjukkan hwa prestasi belajar diterima.

\section{DAFTAR RUJUKAN}

Akcay, N. O., \& Doymus, K. (2014). The of different methods of cooperative learning model on academic achievement in physics. Journal of Turkish science education, volume 11, Issu 4, 17-30.

Becker, J. P. \& Shimada, S. (2005). The open ended approach: a new proposal for teaching mathematics. Reston, Virgina:National Council of Teacher of Mathematics.

Bennet, A. B., Burton, L. J. \& Nelson, L. T. (2012). Mathematics for elementary teachers : a conceptual approach. New York: The McGraw-Hill Companies.

Chick, H. L. \& Vincent, J. L. (Eds.). (2005). Constructing pedagogigal knowledge of problem solving: preservice mathematics teachers. proceedings of the $29^{\text {th }}$ conference of the international group for the psychology of mathematics education, Vol. 2, pp. 225-232.

Cohen, E. G., et,.al.(2004). Teaching cooperative learning; the challenge for teacher education. New York: Press Albany.

D'Augustine, C. \& Smith, C. W. (1992). Teaching elementary school mathematics. Ohio University, Athens: HarperCollins Publishers.

Gillies, R. M. (2007). Cooperative learning; integrating theory and practice. California: Sage Publications.

Hamruni. (2013). Pembelajaran berbasis edutainment: landasan teori dan metode-metode pembelajaran aktifmenyenangkan (PAIKEM). Yogyakarta: Fakultas Ilmu Tarbiyah dan Keguruan UIN Sunan Kalijaga Yogyakarta. 
Handika, Ilham \& Wangid, Muhammad Nur. (2013). Pengaruh pembelajaran berbasis masalah terhadap penguasaan konsep dan keterampilan proses sains siswa kelas V. Universitas Negeri Yogyakarta: Jurnal prima edukasia. ISSN 23384743. Vol 1, no. 1, 2013.

Hendrawan, Dwi Kd Arya., dkk. (2013). Pengaruh metode problem solving terhadap hasil belajar matematika siswa kelas V SD gugus VII kecamatan tejakula. Di uduh pada tanggal 10 Oktober 2014.email:kadekaryadwihendrawan@yahoo.c om1,tut_arni@yahoo.com2,ayanSudiana 48@yahoo.co.id.httpejournal.undiksha.a c.idindex.phpJJPGSDarticleviewFile142 61287.

Karatas, I., \& Baki, A. (2013). The effect of learning environments based on problem solving on students' achievements of problem solving. International electronic journal of elementary education, 5(3), 249-268.

Darmayanti, Laksmi dkk. (2014). Model open ended berbasis reinforcement berpengaruh terhadap hasil belajar IPS siswa kelas V SDN 18 Dangin Puri Denpasar Utara. Jurnal Mimbar PGSD Universitas Pendidikan Ganesha Jurusan PGSD (vol: 2 no: 1 tahun 2014)

Leiba, M. \& Nachmias, R. (2013). Assessing mathematical problem solving behavior in web based environment using educational data mining from correspondence scheme to quantitative analysis. Proceeding of the chais conference on instructional technologies research, 44-52.

Endriana, Neny. (2011). Perbandingan antara pendekatan open ended dan problem possing dalam pembelajaran matematika materi pokok geometri terhadap kemampuan berpikir kreatif dan motivasi belajar siswa SMA/MA NW Narmada. Tesis Magister, Tidak diterbitkan, Universitas Negeri Yogyakarta.

Pimta, S., Tayruakham, S., \& Nuangchalerm, P. (2009). Factors influencing mathematics problem solving ability of sixth grade students. Journal of Social Sciences, 5(4), 381-385.

Setiamihardja, Realin dan Kusmiyati. (2007). Pendekatan Open Ended dalam Pembelajaran Matematika di Sekolah Dasar. Jurnal, Pendidikan Dasar. Nomor: 8 - Oktober 2007.

Slavin, R. E. (1995). Cooperative learning; teory, research, and practice $\left(2^{\mathrm{nd}}\right)$. Sydney: AllymandBroon.

Thobroni, M., \& Mustofa, Ali. (2013). Belajar dan pembelajaran; pengembangan wacana dan praktik pembelajaran dalam pembangunana nasional. Yogyakarta: Ar-ruzz Media 